\title{
Immunocytochemical Localization and Biological Activity of $3 \beta$-Hydroxysteroid Dehydrogenase in the Central Nervous System of the Frog
}

\author{
Ayikoe G. Mensah-Nyagan, ${ }^{1}$ Marc Feuilloley, ${ }^{1}$ Eric Dupont, ${ }^{2}$ Jean-Luc Do-Rego, ${ }^{1}$ François Leboulenger, ${ }^{1}$ \\ Georges Pelletier, ${ }^{2}$ and Hubert Vaudry ${ }^{1}$ \\ 'European Institute for Peptide Research, Laboratory of Cellular and Molecular Neuroendocrinology, University of Rouen, \\ 76821 Mont-Saint-Aignan, France, and ${ }^{2} \mathrm{MRC}$ Group in Molecular Endocrinology, Laval University Hospital Center, Québec \\ G1V 4G2, Canada
}

The enzyme $3 \beta$-hydroxysteroid dehydrogenase $/ \Delta^{5}-\Delta^{4}$ isomerase ( $3 \beta$-HSD) catalyzes biosynthesis of progesterone (P) and all precursors of glucocorticoids, mineralocorticoids, androgens, and estrogens. Despite the broad interest raised by neurosteroids, the cellular localization of $3 \beta$-HSD has never been investigated in the brain. We took advantage of the availability of an antiserum raised against human placental $3 \beta$-HSD to determine the distribution of $3 \beta$-HSD-immunoreactive structures in the brain of the frog Rana ridibunda by the indirect immunofluorescence technique. Three populations of $3 \beta$-HSD-immunoreactive cell bodies were observed in the hypothalamus, namely, in the rostral region of the preoptic nucleus, the dorsal infundibular nucleus, and the dorsal part of the ventral infundibular nucleus. A dense network of $3 \beta$-HSD-immunoreactive nerve fibers was visualized in the dorsal area of the diencephalon, that is, in the lateral neuropil, the corpus geniculatus lateralis, and the nucleus posterolateralis thalami. Reversed-phase HPLC analysis of frog hypothalamic extracts combined with RIA detection showed the presence of substantial amounts of immunoreactive steroids coeluting with $P$ and 17-hydroxyprogesterone (17OH-P). The synthesis of $\Delta^{4}-3-k e t o-s t e r o i d s$ in the frog hypothalamus was investigated using the pulsechase technique with ${ }^{3} \mathrm{H}$-pregnenolone $\left({ }^{3} \mathrm{H}-\Delta^{5} \mathrm{P}\right)$ as a precursor. The formation of five tritiated metabolites of ${ }^{3} \mathrm{H}-\Delta^{5} \mathrm{P}$ was observed, one of which coeluted with 170H-P. Conversion of ${ }^{3} \mathrm{H}-\Delta^{5} \mathrm{P}$ into this radioactive metabolite was significantly reduced by trilostane, a specific inhibitor of $3 \beta-\mathrm{HSD}$. Immunodetection of newly synthesized steroids in HPLC fractions of hypothalamic extracts, using $170 \mathrm{H}-\mathrm{P}$ antibodies, revealed the existence of an immunoreactive steroid that exhiblted the same retention time as synthetic 17OH-P. The

\footnotetext{
Received Jan. 19, 1994; revised May 18, 1994; accepted May 26, 1994.

This work was supported by grants from the Ministère des Affaires Etrangères (France-Québec exchange program), INSERM, CNRS (URA 650), European Science Foundation, and the Conseil Régional de Haute-Normandie. We thank Dr. C. Oliver (INSERM U297, Marseille) for providing the progesterone antiserum, and Dr. F. Collin for the drawings of the atlas of the frog brain.

Correspondence should be addressed to Dr. Marc Feuilloley, European Institute for Peptide Research, Laboratory of Cellular and Molecular Neuroendocrinology, INSERM U 413, UA CNRS, University of Rouen, 76821 Mont-Saint-Aignan, France.

Copyright (C 1994 Society for Neuroscience $0270-6474 / 94 / 147306-13 \$ 05.00 / 0$
}

present study provides the first immunocytochemical mapping of $3 \beta-H S D$, a key enzyme of the steroid biosynthetic pathway, in the CNS of a vertebrate. The data also demonstrate for the first time biosynthesis of neurosteroids in the brain of a nonmammalian vertebrate.

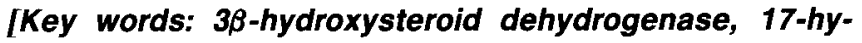
droxy-progesterone, neurosteroids, hypothalamic neurons, pulse chase, immunocytochemistry]

The enzyme $3 \beta$-hydroxysteroid dehydrogenase $/ \Delta^{5}-\Delta^{4}$-isomerase $\left(3 \beta\right.$-HSD) catalyzes the biosynthesis of $\Delta^{4}$-3-ketosteroids from $\Delta^{5}-3 \beta$-hydroxysteroids. This enzyme, which was originally identified in steroid hormone-producing organs such as adrenal, testis, ovary, and placenta, has also been found in other tissues including prostate, breast, liver, kidney, and skin (for review, see Labrie et al., 1992). Different isoforms of $3 \beta$-HSD, expressed in a cell-specific manner, have recently been characterized in mouse (Bain et al., 1991), rat (Zhao et al., 1991), and human (Lachance et al., 1990, 1991).

One of the substrates of $3 \beta$-HSD is pregnenolone $\left(\Delta^{5} \mathrm{P}\right)$, which is generated from cholesterol by cytochrome $\mathrm{P} 450_{\text {scc. }}$. Cytochrome $\mathrm{P} 450_{\text {scc }}$ has been localized in the myelinated regions of the rat brain (Le Goascogne et al., 1987), and cultured rat glial cells have been shown to synthesize $\Delta^{5} \mathrm{P}$ (Jung-Testas et al., 1989). Conversion of $\Delta^{5} P$ to progesterone $(P)$ has been reported in discrete regions of the CNS of the rat, suggesting that an active form of $3 \beta$-HSD is expressed in the brain (Weidenfield et al., 1980). Biosynthesis of androstenedione $\left(\Delta^{4}\right)$ from dehydroepiandrosterone (DHEA), another enzymatic reaction catalyzed by $3 \beta$-HSD, has also been observed in the CNS of the rat (Robel et al., 1986). However, although a $3 \beta$-HSD activity has been detected in primary cultures of rat oligodendrocyles (Jung-Testas et al., 1989) and mouse glial cells and neurons (Bauer and Bauer, 1989), the cellular distribution of $3 \beta$-HSD in the CNS has never been determined. In addition, biosynthesis of steroid hormones has not been investigated before in the CNS of nonmammalian vertebrates.

In the present report, we have studied the distribution of $3 \beta$ HSD in the CNS of the frog Rana ridibunda using an antiserum raised against human placental (type I) $3 \beta$-HSD. We have also investigated the occurrence of $3 \beta$-HSD activity by studying the metabolism of $\Delta^{5} \mathrm{P}$ by frog hypothalamic tissue. 


\section{Materials and Methods}

Animals. Adult male frogs (Rana ridibunda) weighing 30-40 gm were obtained from a commercial source (Couétard, Saint-Hilaire de Riez, France). The animals were kept in glass tanks at $8^{\circ} \mathrm{C}$ under a $12 \mathrm{hr}$ light$12 \mathrm{hr}$ dark cycle for at least 1 week before use. They were allowed free access to running water. Animal manipulations were performed according to the recommendations of the French Ethic Committee and under the supervision of authorized investigators. To limit possible variations due to circadian rhythms (Akwa et al., 1991), all animals were killed between 09:30 and 10:30 hr.

Antisera. The antiserum against $3 \beta$-HSD was raised by immunizing rabbits with purified human placental (type I) $3 \beta$-HSD (Luu-The et al., 1989). Polyclonal rabbit anti-cow glial fibrillary acidic protein (GFAP) scrum (Z334) was purchased from DAKO (Glostrup, Denmark). Monoclonal mouse anti-galactocerebroside (GalC) $\gamma$-globulins (clone D12) were obtained from Boehringer (Mannheim, Germany). Fluorescein isothiocyanate-conjugated goat anti-rabbit (GAR/FITC) and anti-mouse (GAM/FITC) $\gamma$-globulins were supplied by Nordic Immunology (Tilburg, The Netherlands). The $\mathrm{P}$ antiserum was a gift from Dr. C. Oliver (INSERM U297, Marseille, France). The 17-hydroxyprogesterone (17OH-P) antiserum (no. 217-0501) was produced by immunizing rabbits against $17 \mathrm{OH}-\mathrm{P}$ coupled to bovine serum albumin.

Chemicals and reagents. Synthetic steroids including androsterone $(A n)$, corticosterone $(B), \Delta^{4}$, DHEA, estradiol $\left(E_{2}\right), P$, testosterone $(T)$, 11-hydroxyprogesterone (11 OH-P), 17OH-P, 17-hydroxypregnenolone $\left(17 \mathrm{OH}-\Delta^{5} \mathrm{P}\right)$, and dihydrotestosterone $(5 \alpha \mathrm{DHT})$ were supplied by Sigma (St. Louis, MO). Propylene glycol, methanol, and HEPES were purchased from Mcrck (Darmstadt, Germany). Trilostane (WIN 24,540) was a gift from Winthrop Laboratories (Clichy, France). Tritiated $P$ $\left(1,2,6,7-{ }^{3} \mathrm{H}-\mathrm{P}\right)$ and tritiated $17 \mathrm{OH}-\mathrm{P}\left(1,2,6,7-{ }^{3} \mathrm{H}-17 \mathrm{OH}-\mathrm{P}\right)$ were obtained from Amersham International (Buckinghamshire, UK). Tritiated $\Delta^{5} \mathbf{P}\left(7-{ }^{3} \mathrm{H}-\Delta^{5} \mathrm{P}\right)$ was purchased from DuPont-New England Nuclear (Les Ulis, France).

Immunofluorescence procedure. Animals were killed by cervical dislocation and perfused transcardially with $50 \mathrm{ml}$ of $0.1 \mathrm{M}$ phosphatebuffered saline (PBS; pH 7.3) containing $0.025 \%$ xylocaine as an anesthetic. The perfusion was carried on with $50 \mathrm{ml}$ of Bouin's fixative $(75 \mathrm{ml}$ of saturated picric acid, $25 \mathrm{ml}$ of formaldehyde, and $5 \mathrm{ml}$ of acetic acid). The brain, with the attached pituitary, was rapidly dissected and postfixed in the same fixative solution for $24 \mathrm{hr}$. The tissues were immersed in PBS containing 15\% sucrose for $12 \mathrm{hr}$ and then transferred into $30 \%$ sucrose PBS for $24 \mathrm{hr}$. The brains were placed in an embedding medium (OCT Tissue-Tek, Reichert-Jung, Nussloch, Germany) and immediately frozen at $-80^{\circ} \mathrm{C}$. Frontal or sagittal sections $(8 \mu \mathrm{m}$ thick) were cut in a cryostat (Frigocut 2800E, Reichert-Jung, Nussloch, Germany) and mounted on glass slides coated with $0.5 \%$ gelatin and $5 \%$ chromium potassium sulfate. The tissue sections were incubated overnight at $4^{\circ} \mathrm{C}$ with the $3 \beta-\mathrm{HSD}$ antiserum diluted $1: 100$ in PBS containing $0.3 \%$ Triton $X-100$ and $1 \%$ bovine serum albumin. The sections were rinsed three times in PBS for $1 \mathrm{hr}$, and then incubated for $1.5 \mathrm{hr}$ at room temperature with GAR/FITC diluted 1:60. Finally, the sections were rinsed for $1 \mathrm{hr}$ in PBS and mounted with PBS-glycerol (1:1). The preparations were examined under a Leitz Orthoplan microscope or a confocal laser scanning microscope (CLSM, Leica, Heidelberg, Germany) equipped with a Diaplan optical system and an argon/krypton ion laser (excitation wavelengths: $488 / 568 / 647 \mathrm{~nm}$ ).

Nomenclature of brain areas and nuclei was based on the stereotaxic atlas of the CNS of Rana pipiens (Wada et al., 1980).

The specificily of the immunoreaction was controlled by (1) substitution of the $3 \beta$-HSD antiserum with $\mathrm{PB},(2)$ replacement of the $3 \beta$ HSD antiserum by nonimmune rabbit serum, and (3) preincubation of the $3 \beta$-HSD antiserum with human type I $3 \beta$-HSD $\left(10^{-6} \mathrm{M}\right)$.

Consecutive sections of the preoptic nucleus were used for the identification of $3 \beta$-HSD-immunoreactive cells. One section was incubated with the $3 \beta$-HSD antiserum (diluted 1:100) and the adjacent section with GFAP or GalC antiserum (diluted 1:50).

Tissue extraction. Frogs were decapitated and the hypothalamus was quickly removed. Blood was collected by intracardiac puncture. The hypothalamic tissues and the blood samples were homogenized with a glass Potter homogenizer in $2.5 \mathrm{ml}$ of icc-cold $10 \%$ trichloracetic acid (TCA). The samples were then submitted to three successive extractions by $2.5 \mathrm{ml}$ of dichloromethane. The aqueous supernatant was kept and used for determination of protein content in the extract. The organic phases were pooled and the solvent was evaporated on ice under a stream of nitrogen. The dry extracts were redissolved in $1 \mathrm{ml}$ of a solution consisting of $65 \%$ water/TFA $(99.9: 0.1, \mathrm{v} / \mathrm{v} ;$ Sol A) and $35 \%$ methanol/ acetonitrile/TFA (90:9.98:0.02, v/v/v; Sol B). The tissue extracts were prepuritied on Sep-Pak $\mathrm{C}_{18}$ cartridges (Waters Associates, Milford, MA). Steroids were eluted with $3 \mathrm{ml}$ of a solution made of $25 \%$ Sol A and $75 \%$ Sol B. The solvent was evaporated under nitrogen and the extracts were kept dry until HPLC analysis.

To determine the recovery of native steroids during the extraction procedure, samples containing either $1 \mathrm{ml}$ of plasma or four hypothalamic explants were incubated for $10 \mathrm{~min}$ with $10^{8} \mathrm{cpm}$ of ${ }^{3} \mathrm{H}-\mathrm{P}$, homogenized, and extracted as described above. The extraction efficiency from plasma and hypothalamic tissue was $74 \pm 13 \%$ and $83 \pm 11 \%$, respectively.

Pulse-chase technique. For each experiment, the hypothalamus of four frogs was cut into two slices and preincubated for $15 \mathrm{~min}$ in $1 \mathrm{ml}$ of Ringer's solution. The Ringer's buffer consisted of 15 mM HEPES buffer, $112 \mathrm{mM} \mathrm{NaCl}, 15 \mathrm{~mm} \mathrm{NaHCO}, 2 \mathrm{mM} \mathrm{CaCl}_{2}$, and $2 \mathrm{mM} \mathrm{KCl}$, supplemented with $2 \mathrm{mg}$ of glucose $/ \mathrm{ml}$ and $0.3 \mathrm{mg}$ of $\mathrm{BSA} / \mathrm{ml}$. The incubation medium was gassed with a $95 \% \mathrm{O}_{2} / 5 \% \mathrm{CO}_{2}$ mixture and the $\mathrm{pH}$ adjusted to 7.4. The hypothalamic slices were incubated at $24^{\circ} \mathrm{C}$ for $0.5-4 \mathrm{hr}$ in $500 \mu \mathrm{l}$ Ringer's medium containing $10^{-6} \mathrm{M}$ tritiated $\Delta^{5} \mathrm{P}$ and $4 \%$ propylene glycol. At the end of the incubation period, the medium was removed and the tissues rinsed four times with ice-cold Ringer's buffer. The experiment was then stopped by addition of $750 \mu 1$ of TCA. The tissue was homogenized using a glass Potter homogenizer and extracted three times by $1 \mathrm{ml}$ of dichloromethane. The extracts were prepurified on Sep-Pak columns as described above and analyzed by HPLC. Control experiments were performed by replacing hypothalamic tissue by slices of frog rhombencephalon, a brain region that did not contain $3 \beta-\mathrm{HSD}-$ immunoreactive cells.

High-performance liquid chromatography. Tissue extracts were analyzed by reversed-phase HPLC on a Beckmann 344 Gradient Liquid Chromatograph equipped with a Zorbax ODS/ $\mathrm{C}_{18}$ column $(0.46 \times 25$ $\mathrm{cm}$ ) in order to characterize endogenous steroids or radioactive steroids formed by conversion of ${ }^{3} \mathrm{H}-\Delta^{5} \mathrm{P}$. The tissue extracts, prepurified on the Sep-Pak cartridges, were injected onto the HPLC column equilibrated with a solution made of $60 \%$ Sol $A$ and $40 \%$ Sol B (v/v) at a flow rate of $1 \mathrm{ml} / \mathrm{min}$. The concentration of Sol B was raised to $62 \%$ over 28 min and maintained at this concentration for $12 \mathrm{~min}$. Fractions were collected at $0.5 \mathrm{~min}$ intervals. For RIA detection of endogenous $P$ and $17 \mathrm{OH}-\mathrm{P}$ or immunodetection of newly synthesized ${ }^{3} \mathrm{H}-17 \mathrm{OH}-\mathrm{P}$ in the HPLC eluent, the fractions were evaporated in a Speed Vac Concentrator (Savant, Hicksville, NY) and kept dry until assay. For measurement of radioactive metabolites of ${ }^{3} \mathrm{H}-\Delta^{5} \mathrm{P}, 400 \mu \mathrm{l}$ of each HPLC fraction was mixed with $4 \mathrm{ml}$ of liquid scintillator (Aquasafe 300 Plus, Zinner Analytic, Frankfurt, Germany) and counted in a liquid scintillation counter (LKB 1217 Rackbeta, Rockville, MD).

In a series of experiments, labeled steroids formed from ${ }^{3} \mathrm{H}-\Delta^{5} \mathrm{P}$ in hypothalamic tissue were analyzed on a Nova-Pak $\mathrm{C}_{18}$ column $(0.39 \times$ $30 \mathrm{~cm})$ equilibrated with $60 \%$ water/TFA $(99.9: 0.1, \mathrm{v} / \mathrm{v}$; Sol A) and 40\% methanol/water/TFA (90:9.98:0.02, v/v/v; Sol C) at a flow rate of $1 \mathrm{ml} / \mathrm{min}$. Steroids were separated using a gradient of Sol C $(40-80 \%$ over $70 \mathrm{~min}$ ) including three isocratic steps at $40 \%, 64 \%$, and $80 \% \mathrm{Sol}$ C. Tritiated compounds eluted from the HPLC column were detected using a flow scintillation analyzer (Radiomatic Flo-One/Beta A-500, Packard, Meriden, CT) equipped with a 486DX50 PC computer.

Synthetic steroids used as reference standards were chromatographed under the same conditions as the tissue extracts and detected by ultraviolet absorption using an ISCO-UV detector (model 1840).

Measurement of endogenous $P$ and $17 O H-P$. For each assay, 20 frog hypothalami or $1 \mathrm{ml}$ of blood was used. The amount of endogenous $\mathrm{P}$ and $17 \mathrm{OH}-\mathrm{P}$ was determined by RIA after HPLC analysis of the tissue extracts. Dried HPLC fractions were dissolved in $500 \mu \mathrm{l}$ of $0.1 \mathrm{M}$ borate buffer ( $\mathrm{pH} 7.8$ ) and sonicated. The final dilutions of the $\mathrm{P}$ and $17 \mathrm{OH}-\mathrm{P}$ antisera used were $1: 24,000$ and $1: 14,000$, respectively.

Immunodetection technique. Pulse-chase HPLC fractions were reconstituted in $900 \mu \mathrm{l}$ of $0.1 \mathrm{M}$ borate buffer ( $\mathrm{pH} \mathrm{7.8).} \mathrm{The} \mathrm{samples} \mathrm{were}$ incubated overnight at $4^{\circ} \mathrm{C}$ with an excess of the $17 \mathrm{OH}-\mathrm{P}$ antiserum (diluted 1:5000). Control experiments were performed by substituting the $17 \mathrm{OH}-\mathrm{P}$ antiserum with nonimmune rabbit serum (diluted 1:5000) to determine nonspecific binding. Separation of bound and free radioactive steroids was performed by addition of $500 \mu \mathrm{l}$ of a charcoal suspension ( $1 \%$ Norit charcoal and $1 \%$ dextran T70 in $0.1 \mathrm{~m}$ borate buffer). After centrifugation, the supernatant was collected and counted for detection of antibody-bound radioactive steroids. 
Table 1. Localization and relative abundance of $3 \beta$-HSD-immunoreactive cells and fibers in the brain of the frog Rana ridibunda

Structure

Cell bodies

Fibers

Telencephalon

Nucleus olfactorius anterior (NOA)

Bulbus olfactorius, mitral cell layer (BOml)

Bulbus olfactorius accessorius (BOA)

Vomeronasal nerve (VN)

Pallium dorsalis (PD)

Pallium mediale (PM)

Pallium laterale, pars dorsalis (PLd)

Pallium laterale, pars ventralis (PLv)

Nucleus medialis septi (NMS)

Nucleus accumbens septi (NAS)

Nucleus lateralis septi (NLS)

Striatum, pars dorsalis (STd)

Striatum, pars ventralis (STv)

Medial forebrain bundle (MFB)

Nucleus diagonal band of broca (NDB)

Amygdala, pars lateralis (Al)

Amygdala, pars medialis (Am)

Nucleus entopeduncularis (NEP)

Pallial commissure ( $\mathrm{PaC})$

Bed nucleus of the pallial commissure (NPBC)

Anterior commissure (AC)

Diencephalon

Epiphysis (E)

Habenular commissure (HC)

Nucleus habenularis dorsalis (NHD)

Nucleus habenularis ventralis (NHV)

Area ventralis anterior thalami (AVA)

Area ventrolateralis thalami (AVL)

Area ventromedialis thalami (AVM)

Nucleus dorsomedialis anterior thalami (NDMA)

Nucleus dorsolateralis anterior thalami (NDLA)

Corpus geniculatus lateralis (CGL)

Lateral forebrain bundle (LFB)

Nucleus rotondus (NR)

Nucleus posterocentralis thalami (NPC)

Nucleus posterolateralis thalami (NPL)

Nucleus preopticus (NPO)

Nucleus infundibularis dorsalis (NID)

Nucleus infundibularis ventralis (NIV)

Median eminence (ME)

Structure

Posterior commissure (PC)

Optic chiasma (OC)

Optic tract (OT)

Optic nerve (ON)

Mesencephalon

Nucleus mesencephalicus nervi trigemini (NMNT)

Stratum griseum superficiale tecti (SGS)

Stratum griseum centrale tecti (SGC)

Stratum griseum periventriculare tecti (SGP)

Nucleus of the film (NF)

Nucleus profondus mesencephali (NPM)

Nucleus anterodorsalis tegmenti mesencephali (NAD)

Nucleus anteroventralis tegmenti mesencephali (NAV)

Nucleus posterodorsalis tegmenti mesencephali (NPD)

Nucleus posteroventralis tegmenti mesencephali (NPV)

\begin{tabular}{|c|c|}
\hline- & - \\
\hline- & - \\
\hline- & - \\
\hline- & - \\
\hline- & - \\
\hline- & - \\
\hline- & - \\
\hline- & - \\
\hline- & - \\
\hline- & ++ \\
\hline- & - \\
\hline- & - \\
\hline- & + \\
\hline- & + \\
\hline- & + \\
\hline- & + \\
\hline- & - \\
\hline- & + \\
\hline- & - \\
\hline- & - \\
\hline- & - \\
\hline- & - \\
\hline- & - \\
\hline- & - \\
\hline- & + \\
\hline- & - \\
\hline- & ++ \\
\hline- & - \\
\hline- & + \\
\hline- & ++ \\
\hline- & +++ \\
\hline- & + \\
\hline- & - \\
\hline- & + \\
\hline- & ++ \\
\hline+++ & +++ \\
\hline+++ & +++ \\
\hline++ & ++ \\
\hline- & - \\
\hline- & - \\
\hline- & - \\
\hline$\cdots$ & - \\
\hline- & - \\
\hline- & - \\
\hline- & ++ \\
\hline- & - \\
\hline- & - \\
\hline- & - \\
\hline- & - \\
\hline- & - \\
\hline- & - \\
\hline- & - \\
\hline- & - \\
\hline
\end{tabular}




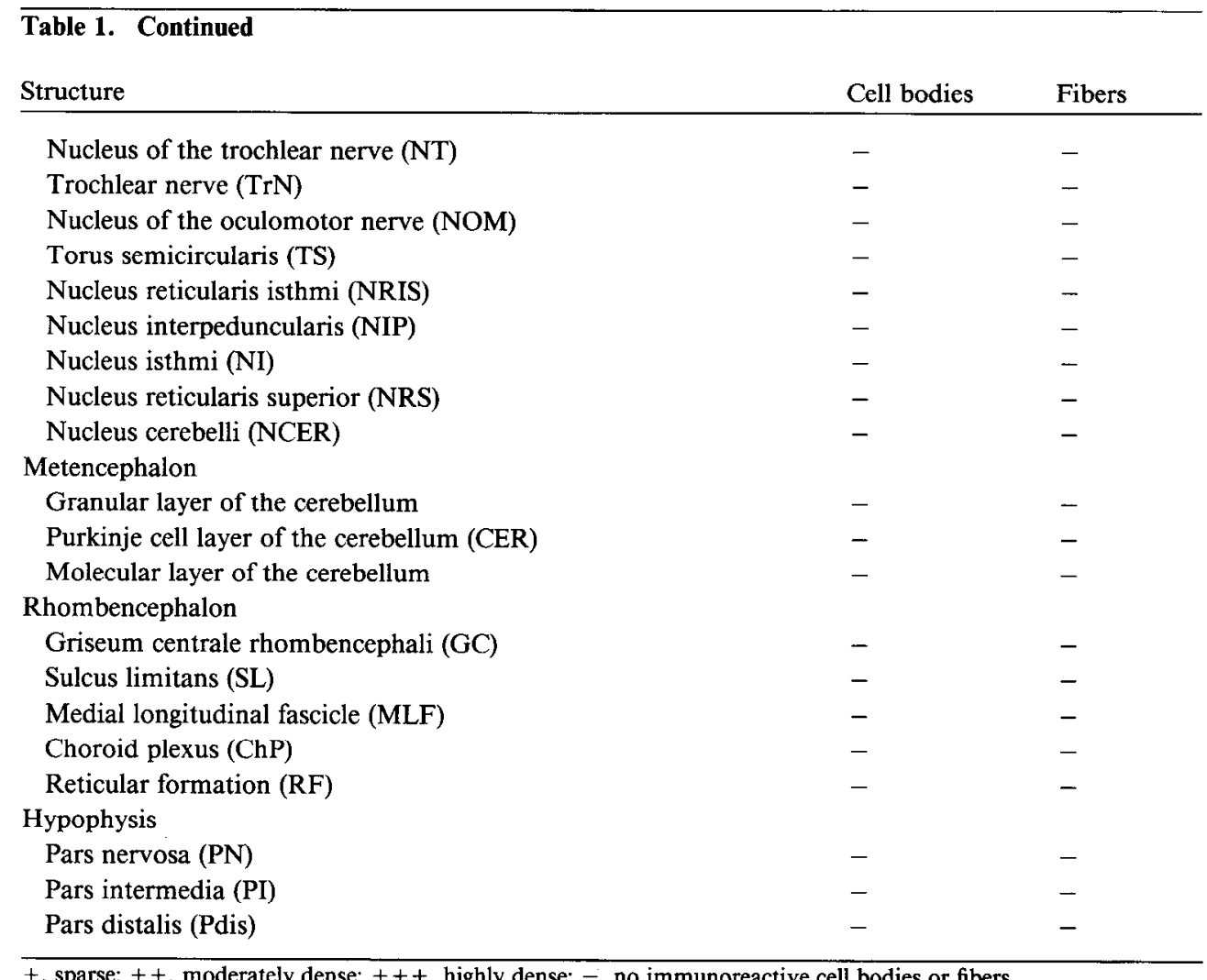

+ , sparse; ++ , moderately dense;,+++ highly dense; - , no immunoreactive cell bodies or fibers.

\section{Results}

\section{Immunocytochemical localization of $3 \beta-H S D$}

The distribution of $3 \beta$-HSD-like immunoreactivity in the frog brain is schematically presented in Figure 1. Table 1 summarizes the localization and relative abundance of immunoreactive cell bodies and fibers.

In the telencephalon, a thin network of $3 \beta$-HSD-immunoreactive fibers was observed at the basis of the lateral ventricles in the nucleus accumbens septi. Sparse fibers were also seen in the pars ventralis of the striatum, the medial forebrain bundle, the nucleus of the diagonal band of Broca, the pars lateralis of the amygdala, and the nucleus entopeduncularis.

The diencephalon contained three populations of $3 \beta$-HSDimmunoreactive cell bodies that were all located in the hypothalamus, namely, in the rostral part of the preoptic nucleus (Fig. 2A), the dorsal infundibular nucleus (Fig. 2B), and the dorsal region of the ventral infundibular nucleus (Fig. 2C). Examination of the hypothalamic neurons with a confocal laser scanning microscope showed that the immunoreactive material had a granular aspect and was apparently sequestered in organelles located in the cytoplasm and cytoplasmic extensions (Fig. $2 D$ ). $3 \beta$-HSD-immunoreactive fibers, which exhibited a characteristic varicose appearance, were also observed in the ventral hypothalamic nuclei (Fig. $2 E$ ). A dense bundle of $3 \beta$-HSDpositive fibers, which was cut transversely on frontal sections, was visualized in the dorsal region of the diencephalon, that is, in the corpus geniculatus lateralis and the nucleus posterolateralis thalami (Fig. $2 F$ ). A few positive fibers were also observed in the nucleus habenularis ventralis, the nucleus dorsolateralis anterior thalami, the nucleus posterocentralis thalami, and ven- trally in the area ventrolateralis thalami and the lateral forebrain bundle.

The metencephalon, rhombencephalon, spinal cord, and pituitary were virtually devoid of immunoreactive elements. A few fibers arising from the dorsal part of the diencephalon terminated in the stratum griseum superficiale tecti of the mesencephalon.

Preincubation of the $3 \beta$-HSD antiserum with purified human type I $3 \beta$-HSD $\left(10^{-6} \mathrm{M}\right)$ resulted in complete disappearance of the immunostaining (Fig. $3 A, B$ ). Labeling of consecutive sections with the $3 \beta$-HSD antiserum and with antisera directed against GFAP (Fig. $3 C, D$ ) or GalC (Fig. $3 E, F$ ) showed that the $3 \beta$-HSD-immunoreactive material was not localized in GFAPor GalC-containing cells. In contrast, strong labeling of glial cells was observed with the GFAP and GalC antisera in the optic tract and amygdala, respectively (data not shown).

\section{Measurement of endogenous $P$ and $170 \mathrm{OH}-\mathrm{P}$}

The detection limit of the RIAs, corresponding to $5 \%$ displacement of the antibody-bound tracer, was $90 \mathrm{pg}$ for the P RIA and $35 \mathrm{pg}$ for the $17 \mathrm{OH}-\mathrm{P}$ RIA. The $\mathrm{P}$ antiserum showed $7.5 \%$ cross-reaction with $\Delta^{5} \mathrm{P}$ but did not cross-react with $17 \mathrm{OH}-\mathrm{P}$. The $17 \mathrm{OH}-\mathrm{P}$ antiserum showed $1 \%$ cross-reaction with $\mathrm{P}, 0.85 \%$ with $\Delta^{s} \mathrm{P}$, and $0.8 \%$ with $17 \mathrm{OH}-\Delta^{5} \mathrm{P}$. The cross-reactivity of the $\mathrm{P}$ and $17 \mathrm{OH}-\mathrm{P}$ RIAs with $\mathrm{T}, 5 \alpha \mathrm{DHT}$, and $\mathrm{E}_{2}$ was lower than $0.1 \%$. HPLC analysis of hypothalamic extracts combined with RIA detection of $P$ revealed the presence of endogenous $P$ in the frog hypothalamus (Fig. $4 A$ ). A peak of $\Delta^{5} \mathrm{P}$ was also detected, owing to the cross-reactivity of $\Delta^{5} P$ in the P RIA. A low amount of $P$ was also detected in the HPLC fractions from blood extracts (Fig. $4 B$ ). Similarly, the presence of endogenous $17 \mathrm{OH}-\mathrm{P}$ 

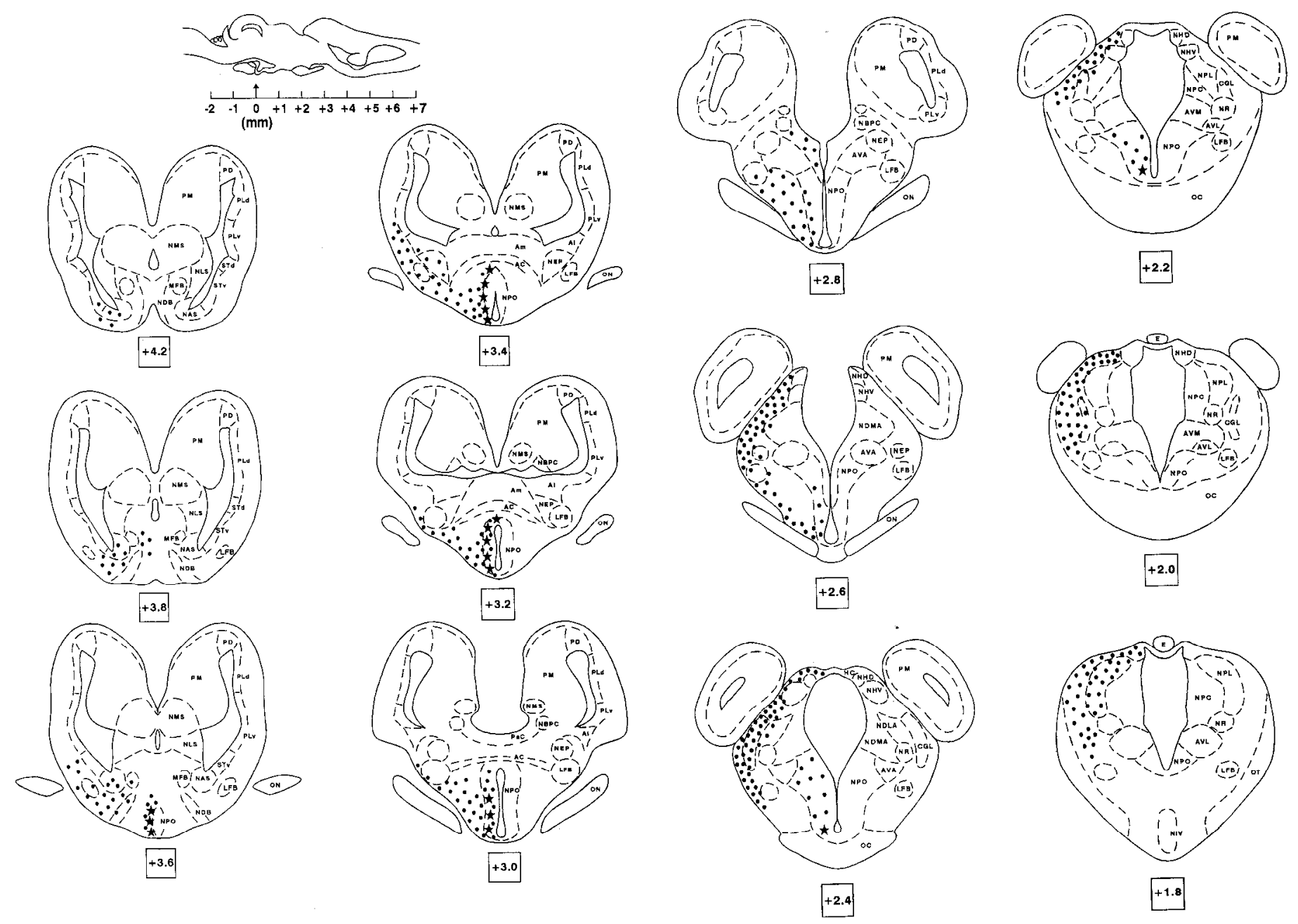

Figure 1. Schematic frontal sections illustrating the distribution of $3 \beta$-HSD-immunoreactive cell bodies ( $\star$ ) and fibers ( $(\bullet)$ in the CNS of Rana ridibunda. The anatomical structures are designated on the right hemisections according to the nomenclature of Wada et al. (1980). The density of the symbols is meant to be proportional to the relative density of the immunoreactive elements. The number under each drawing indicates the rostrocaudal level of the section as shown on the parasagittal schema. Abbreviations are as in Table 1.

in frog hypothalamic extracts was demonstrated by combining HPLC analysis and RIA detection (Fig. 4 C). Two peaks coeluting with $\mathrm{P}$ and $\Delta^{5} \mathrm{P}$ were also detected by the $17 \mathrm{OH}-\mathrm{P}$ RIA method. 17OH-P was not detectable in HPLC fractions of blood extracts (Fig. 4D). The concentrations of $\mathrm{P}$ and $17 \mathrm{OH}-\mathrm{P}$ in the hypothalamic extracts, determined from the areas under the peaks in the respective chromatograms, were $6.8 \pm 1.2$ and 2.1 $\pm 0.4 \mathrm{ng} / \mathrm{mg}$ proteins, respectively $(n-4)$. The concentration of $\mathrm{P}$ in the blood extracts was $0.06 \pm 0.03 \mathrm{ng} / \mathrm{mg}$ proteins $(n$ $=3$ ).

\section{Pulse-chase experiments}

A $2 \mathrm{hr}$ incubation of frog hypothalamic slices with ${ }^{3} \mathrm{H}-\Delta^{5} \mathrm{P}$ yielded the formation of several radioactive metabolites. Reversedphase HPLC analysis of the tissue extracts made it possible to resolve five radioactive peaks (Fig. $5 A$ ), one of which (peak 3) had the same retention time as $17 \mathrm{OH}-\mathrm{P}, \Delta^{4}$, and T. Conversely, incubation of rhombencephalon slices with ${ }^{3} \mathrm{H}-\Delta^{5} \mathrm{P}$ led only to the formation of a small amount of peak 1 (Fig. $5 B$ ).

Hypothalamic slices were incubated for various durations with ${ }^{3} \mathrm{H}-\Delta^{5} \mathrm{P}$ and the radioactive metabolites were analyzed by HPLC. The kinetics of formation of peak 3 are shown in Figure 6. A substantial amount of radioactive metabolite was detected after
30 min of incubation, and the relative quantity of radioactivity contained in peak 3 reached a maximum within $1 \mathrm{hr}$. After 4 hr of incubation, peak 3 markedly declined.

Trilostane, a specific inhibitor of $3 \beta$-HSD, was used to demonstrate further the involvement of $3 \beta$-HSD activity in the formation of peak 3. Incubation of frog hypothalamic slices with $10^{-4} \mathrm{M}$ trilostane induced a significant reduction $(-34 \% ; P<$ 0.05 ) of the conversion of ${ }^{3} \mathrm{H}-\Delta^{5} \mathrm{P}$ into peak 3 metabolites (Fig. 7).

Extracts of hypothalamus explants incubated for $2 \mathrm{hr}$ with ${ }^{3} \mathrm{H}-\Delta^{5} \mathrm{P}$ were analyzed using a different HPLC system equipped with a flow scintillation analyzer that permitted separation of $17 \mathrm{OH}-\mathrm{P}, \mathrm{T}$, and $\Delta^{4}$. In these conditions, radioactive metabolites coeluting with $5 \alpha \mathrm{DHT}, 17 \mathrm{OH}-\Delta^{\mathrm{s}} \mathrm{P}, 17 \mathrm{OH}-\mathrm{P}$, and $\mathrm{P}$ were resolved (Fig. 8).

\section{Immunodetection of radiolabeled $17 \mathrm{OH}-\mathrm{P}$}

Hypothalamic slices were incubated with $10^{-6} \mathrm{M}^{3} \mathrm{H}-\Delta^{5} \mathrm{P}$ for 2 $\mathrm{hr}$ and the tissue extract analyzed by HPLC (Fig. $9 A$ ). Incubation of all HPLC fractions with the $17 \mathrm{OH}-\mathrm{P}$ antiserum revealed the existence of two peaks that apparently contained 17OH-P-like immunoreactivity (Fig. 9B). These peaks exhibited the same retention time as $17 \mathrm{OH}-\mathrm{P}$ and $\Delta^{s} \mathrm{P}$, respectively. Incubation of 

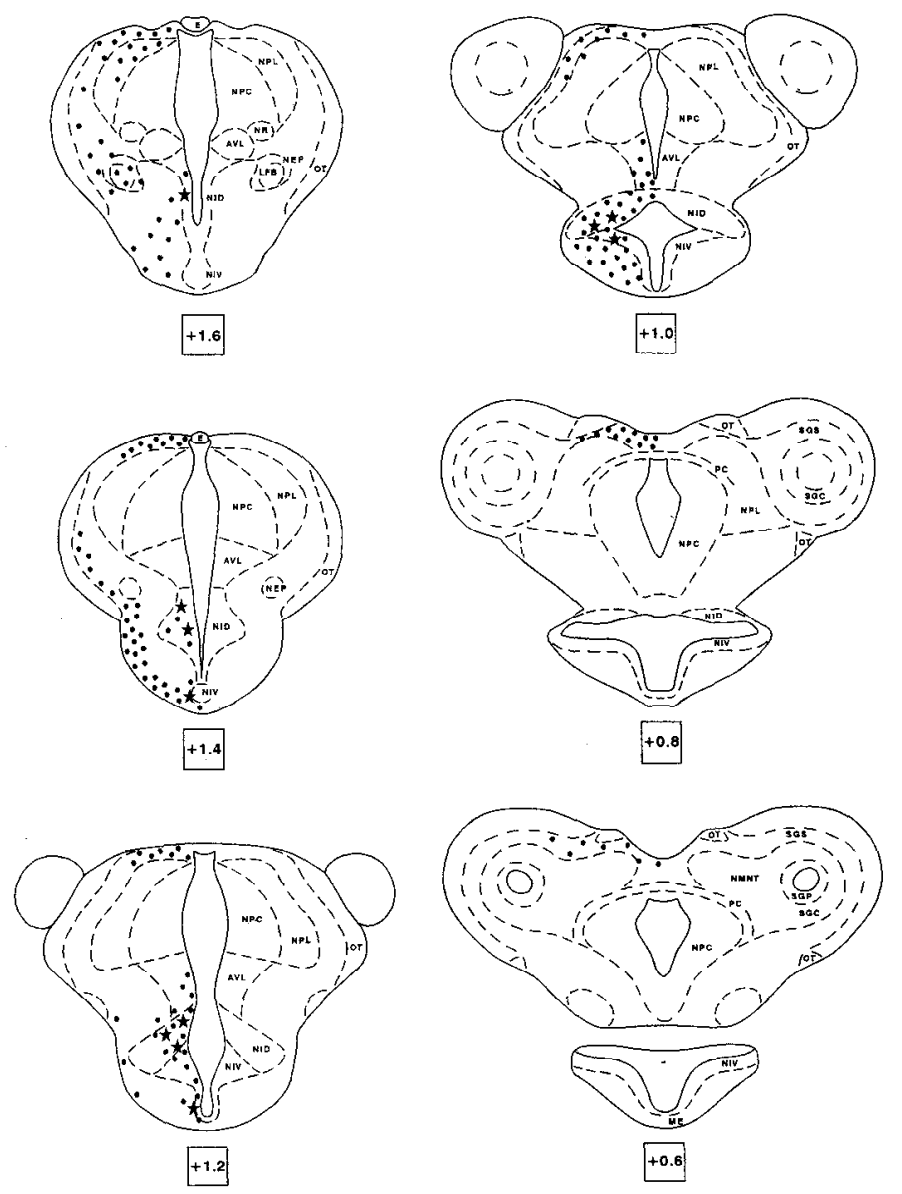

Figure 1. Continued.

the HPLC fractions with a nonimmunc rabbit scrum showed that the second peak, coeluting with $\Delta^{5} \mathrm{P}$, was attributable to the large excess of tracer that could not be totally adsorbed by the charcoal suspension during separation (Fig. 9C).

\section{Discussion}

Biochemical studies have previously demonstrated the occurrence of $3 \beta$-HSD activity in primary cultures of glial cells and/ or neurons from newborn rats (Jung-Testas et al., 1989) and mouse embryos (Bauer and Bauer, 1989). The present work provides the first immunocytochemical description of the distribution of $3 \beta-H S D$ in the CNS of vertebrates. This report also demonstrates that hypothalamic tissue from adult frogs displays $3 \beta$-HSD activity in vivo and in vitro.

\section{Occurrence of $3 \beta$-HSD-like immunoreactivity in frog hypothalamic neurons}

We have taken advantage of the availability of specific $3 \beta$-HSD antibodies to determine the anatomical distribution and cellular localization of $3 \beta$-HSD-like immunoreactivity in the CNS of the frog. The $3 \beta$-HSD antiserum used in this study has already been successfully applied to the immunocytochemical localization of $3 \beta$-HSD in "conventional" steroid-producing organs of mammals, such as the adrenal, testis, ovary, and placenta (Dupont et al., 1990a-c). The preadsorption experiments described herein confirmed the specificity of the immunostaining. However, although the antibodies were raised against type I human placental $3 \beta$-HSD (Luu-The et al., 1989), they also recognize other $3 \beta$-HSD isotypes, in particular, type II $3 \beta$-HSD (Dupont et al., 1990a-c), which is the predominant form expressed in the adrenal and gonads (Lachance et al., 1991). Therefore, the immunoreactive material detected in the frog brain may correspond to any variant(s) of the $3 \beta$-IISD family.

The cells exhibiting $3 \beta$-HSD-like immunoreactivity were exclusively found in three discrete hypothalamic nuclei. The most rostral group of positive cell bodies was located in the preoptic nucleus, a formation that is homologous to the supraoptic and paraventricular nuclei of the brain of mammals (Wada et al., 1980). Two other populations of immunoreactive cells were found more caudally in the dorsal and ventral infundibular nuclei. Anatomically and functionally, the ventral infundibular nucleus of amphibians is homologous to the arcuate nucleus of mammals (Wada et al., 1980). Specifically, in both amphibians and mammals, these nuclei contain several populations of neurons that synthesize a wide range of regulatory neuropeptides (Jacobowitz, 1988; Andersen et al., 1992). A dense bundle of $3 \beta$-HSD-immunoreactive fibers was detected in the lateral tegmentum of the frog, particularly in the lateral thalamic neuropil, the corpus geniculatus lateralis, and the nucleus posterolateralis thalami. In amphibians as in mammals, all these structures that receive tectal afferences are thought to participate in the formation of a tectotegmentospinal pathway (Masino and Grobstein, 1990). A discrete network of $3 \beta$-HSD-immunoreactive fibers was also visualized in the nucleus accumbens septi, a formation that is homologous to the septum of mammals (Northcutl and Kicliter, 1980).

Identification of astrocytes with antisera against GFAP (Nagle, 1988) and oligodendrocytes with antisera against GalC (Raff et al., 1978) revealed that, in the frog brain, the $3 \beta$-HSD-immunoreactive material is not expressed in glial cells. In addition, the $3 \beta$-HSD-positive fibers visualized in the diencephalon and telencephalon exhibited the typical varicose aspect of beaded

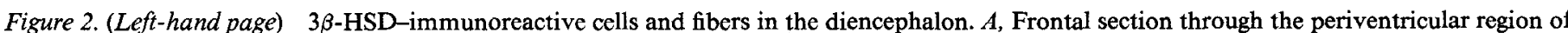

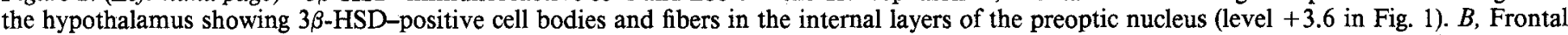

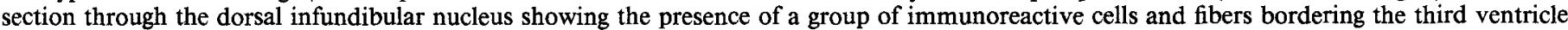

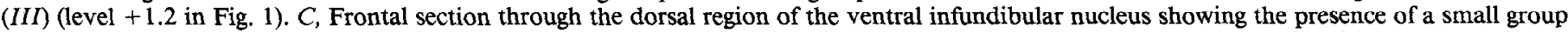

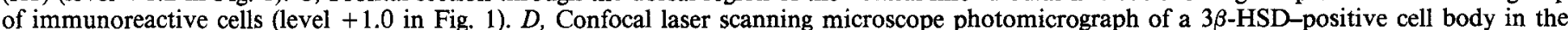

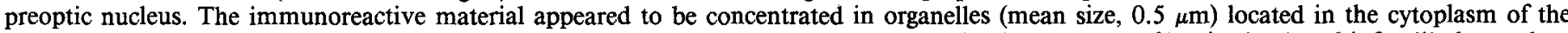

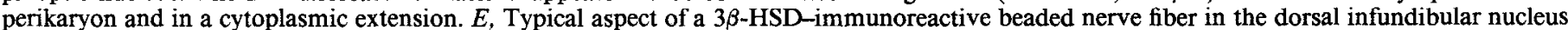

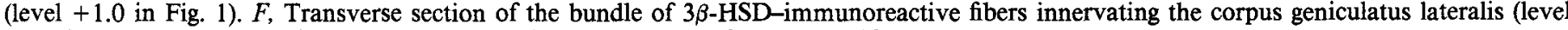
+2.4 in Fig. 1). $P R$, preoptic recess; $N$, nucleus. Scale bars: $A-C, 50 \mu \mathrm{m} ; D-F, 10 \mu \mathrm{m}$.

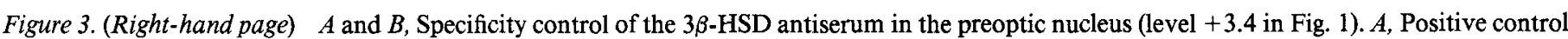

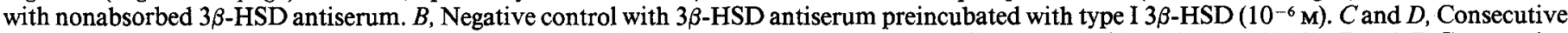

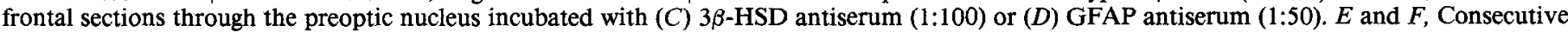

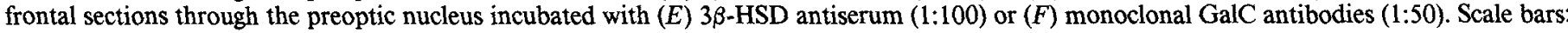
$A$ and $B, 50 \mu \mathrm{m} ; C-F, 10 \mu \mathrm{m}$. 

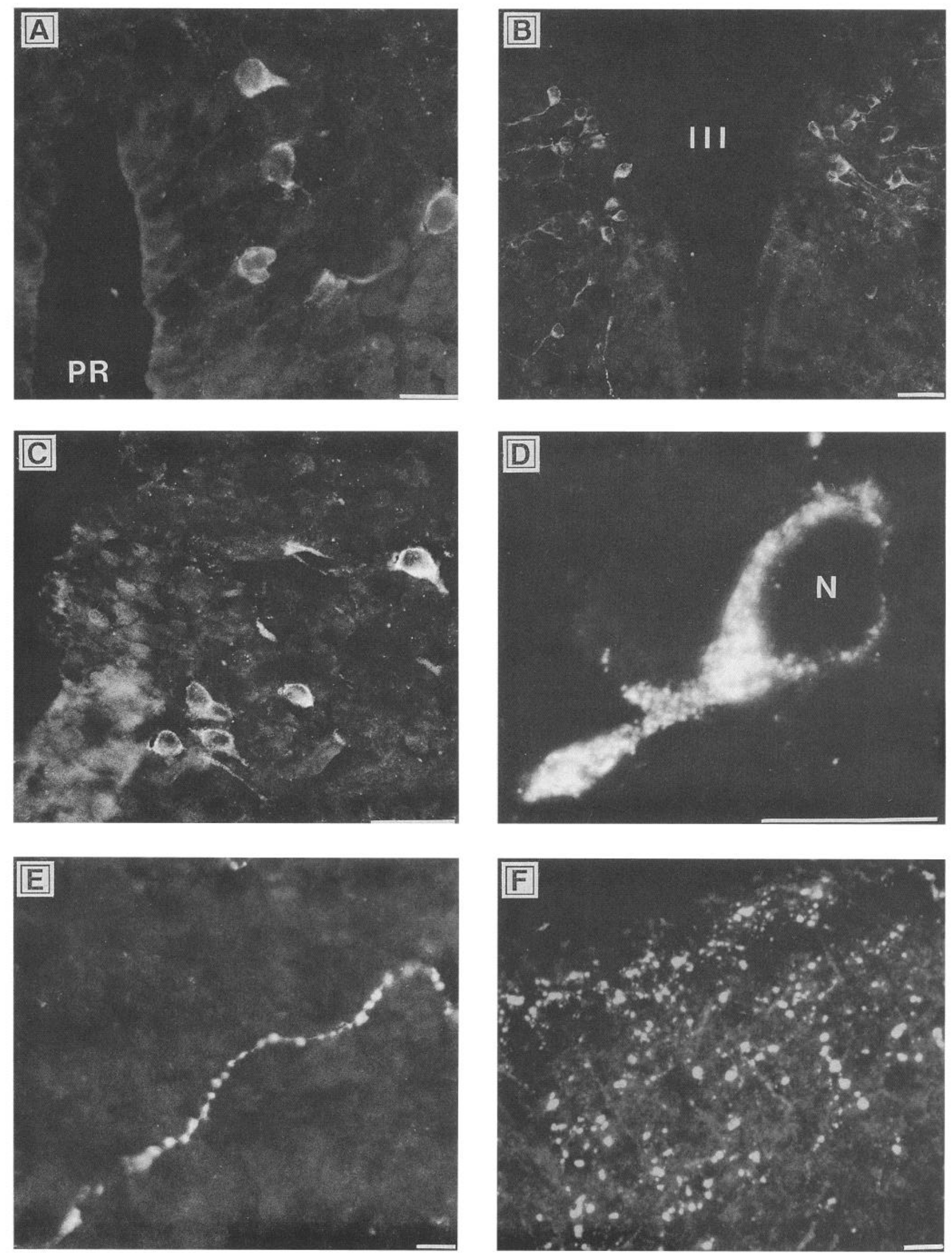

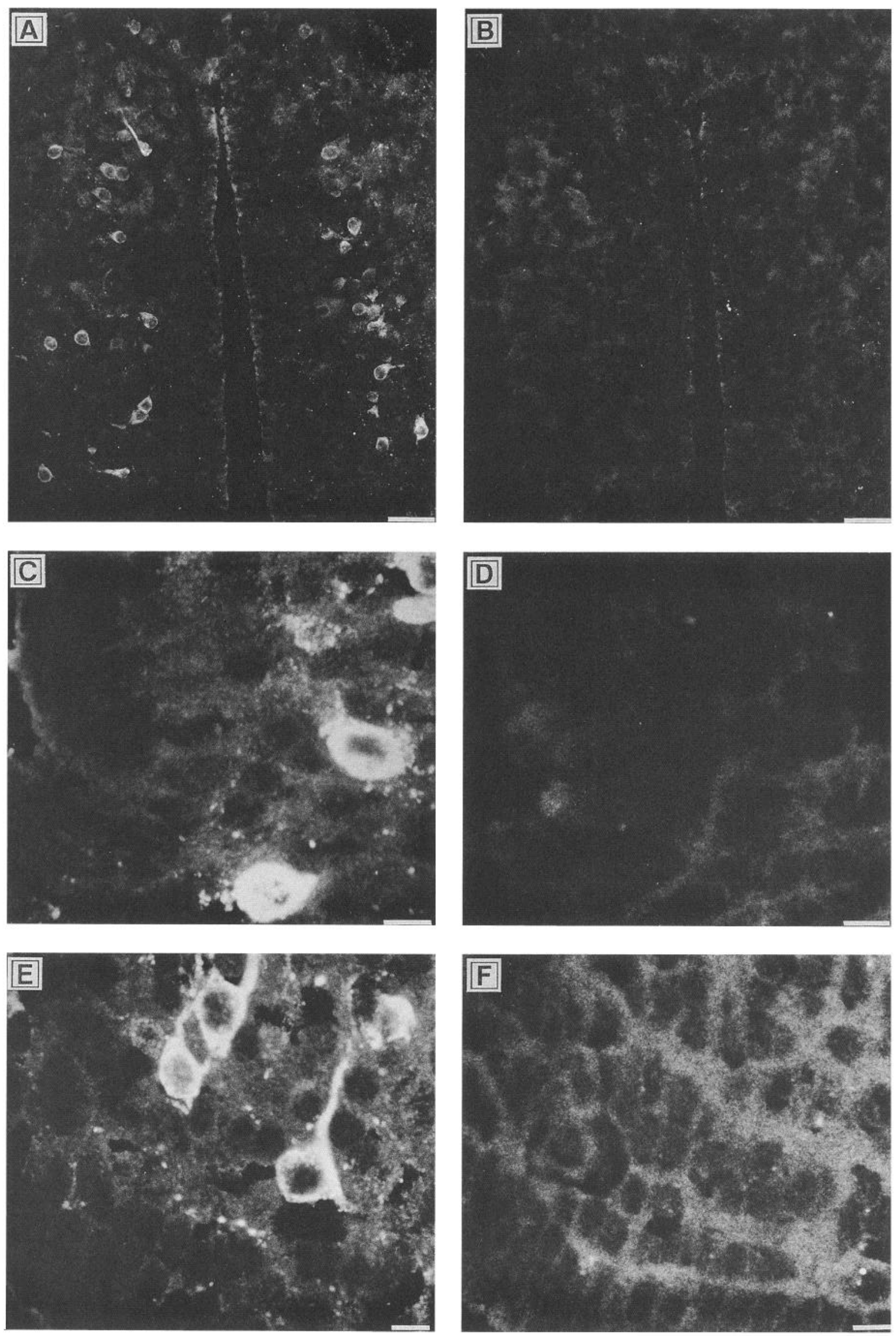


\section{HYPOTHALAMIC EXTRACTS}
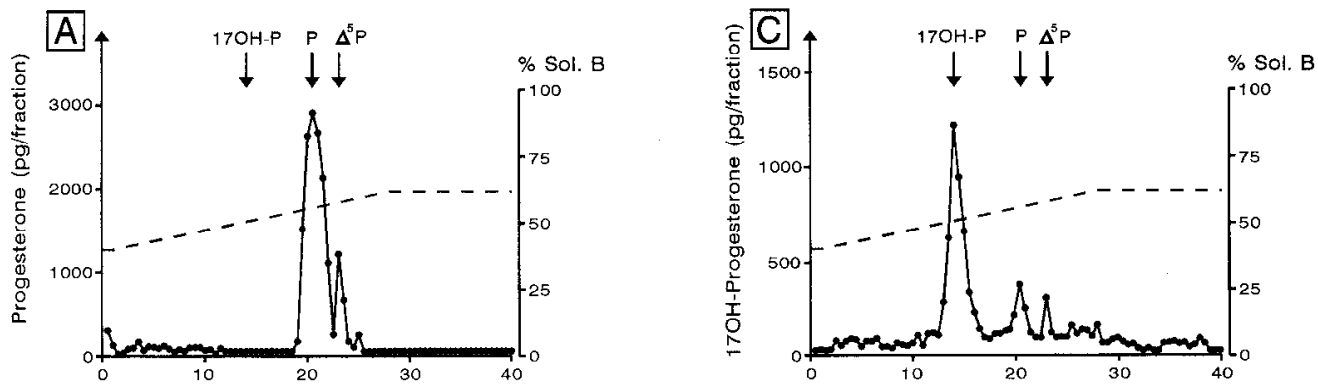

\section{BLOOD EXTRACTS}
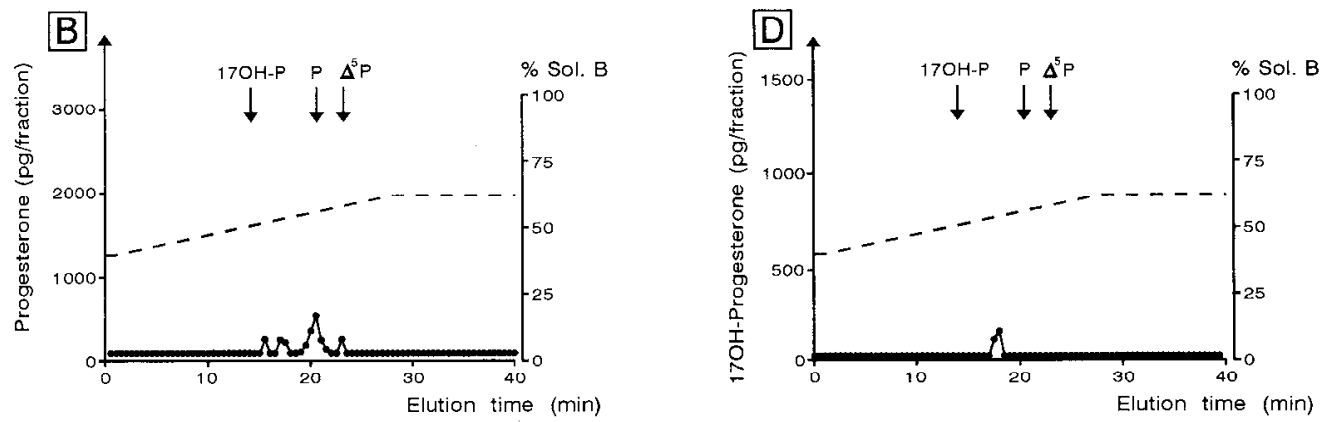

Figure 4. HPLC analysis and radioimmunoassay quantification of progesterone and 17 hydroxyprogesterone in hypothalamic extracts $(A, C)$ and blood extracts $(B, D)$. The dashed line represents the gradient of secondary solvent (\% Sol B). The arrows indicate the elution position of $17-$ hydroxyprogesterone $(17 O H-P)$, progesterone $(P)$, and pregnenolone $\left(\Delta^{5} P\right)$.

nerve fibers, whereas neuroglial and ependymal cells display only thick and linear processes (Oksche and Ueck, 1976; Malagon et al., 1992). These observations indicate that in the frog brain, the $3 \beta$-HSD-immunoreactive material is exclusively expressed in neurons. In agreement with this finding, it has been recently demonstrated that in rat, mRNAs encoding for type I $3 \beta$-HSD are synthesized only in neurons (Dupont et al., 1994). However, since $3 \beta$-HSD enzymatic activity has been detected in cultures of glial cells from fetus (Kabbadj et al., 1993) and newborn rat brains (Jung-Testas et al., 1989), it appears that other isoforms of $3 \beta$-HSD may also be expressed in non-neuronal cells.

To our knowledge, the distribution of $3 \beta$-HSD-immunoreactive neurons has never been determined before in the CNS of any species. Therefore, the immunocytochemical mapping of $3 \beta$-HSD described herein can only be compared to the regional distribution of $3 \beta$-HSD activity previously reported in the rat brain. In agreement with the present findings, $3 \beta-\mathrm{HSD}$ activity has been detected in rat septum (which is homologous to the frog nucleus accumbens septi) and hypothalamus (Weidenfeld et al., 1980; Robel et al., 1986). The absence of significant $3 \beta$-HSD activity in the cerebellum and in the cerebral cortex of the rat (Weidenfeld et al., 1980; Robel et al., 1986) is also consistent with the present data. In contrast, a high level of $3 \beta$-HSD activity has been reported in the rat amygdala (Weidenfeld et al., 1980) while only a few $3 \beta$-HSD-positive fibers were visualized in the frog amygdala. Similarly, $3 \beta$-HSD activity has been detected in the rat hippocampus, whereas the frog pallium (which is homologous of the hippocampal formation of mammals) was virtually devoid of $3 \beta$-HSD-immunoreactive elements. These differences may be ascribed to the presence of isoforms of $3 \beta$-HSD that were not detected by the antiserum.

\section{Presence of endogenous $\Delta^{4}$-3-ketosteroids in the frog} hypothalamus

HPLC analysis of tissue extracts combined with RIA detection revealed the presence of substantial amounts of $\mathrm{P}-$ and $17 \mathrm{OH}-$ P-immunoreactive compounds in the frog hypothalamus. In fact, the concentration of $P$ in the frog hypothalamus was only four times lower than that detected in the adrenal gland, which, in the male frog, is the main source of plasma $P$ (Leboulenger ct al., 1981). Previous studies have demonstrated that, in male rats, the concentrations of $P$ in brain and plasma are in the same range, that is, $2.5 \mathrm{ng} / \mathrm{gm}$ tissue (Corpéchot et al., 1993). Conversely, in male frogs, the concentration of $P$ was 100 times higher in hypothalamic extracts than in plasma, while $17 \mathrm{OH}-\mathrm{P}$ was not detectable in frog blood. Therefore, our results strongly suggest that synthesis of $\mathrm{P}$ and $17 \mathrm{OH}-\mathrm{P}$ occurs in the frog hypothalamus. However, these data do not exclude the possibility that a proportion of brain steroids could originate from selective uptake of $P$ from the plasma.

\section{Conversion of $\Delta^{5} \mathrm{P}$ into $\mathrm{P}$ and $17 \mathrm{OH}-\mathrm{P}$ by hypothalamic explants}

To demonstrate that synthesis of $\mathrm{P}$ and $17 \mathrm{OH}-\mathrm{P}$ actually occurred in the frog hypothalamus, pulse-chase experiments were conducted to investigate the conversion of tritiated $\Delta^{s} \mathbf{P}$ into radioactive metabolites. The data described herein showed that hypothalamic slices exhibit the capability of synthesizing various steroids from $\Delta^{s} \mathrm{P}$. In particular, the results provide strong evidence for $3 \beta$-HSD bioactivity in frog hypothalamic tissue: (1) part of the newly synthesized steroids exhibited the same retention time as $\mathrm{P}$ and $17 \mathrm{OH}-\mathrm{P}$ in different chromatographic systems; (2) the conversion of ${ }^{3} \mathrm{H}-\Delta^{\mathrm{s}} \mathrm{P}$ into these metabolites 


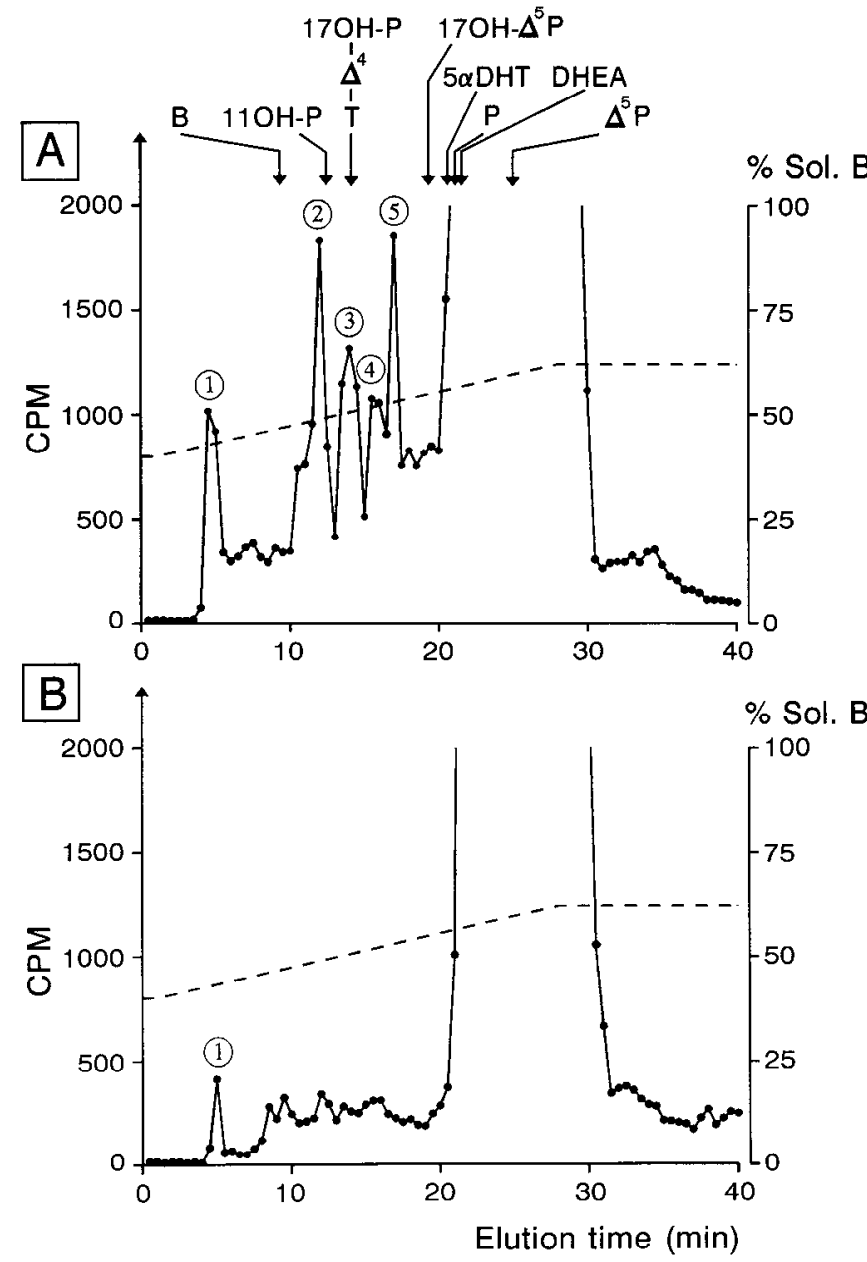

Figure 5. HPLC analysis of steroids extracted from $(A)$ hypothalamic slices or $(B)$ rhombencephalon slices after a $2 \mathrm{hr}$ incubation with ${ }^{3} \mathrm{H}$ pregnenolone using a water-TFA/methanol-acetonitrile gradient. The ordinate indicates the radioactivity measured in the HPLC fractions $(0.5 \mathrm{ml}$ each). The dashed line represents the gradient of secondary solvent (\% Sol B). The peaks of radioactive steroids are designated by consecutive numbers $(1-5)$. The arrows indicate the elution position of standard steroids: $B$, corticosterone; $11 O H-P, 11$-hydroxyprogesterone; $17 \mathrm{OH}$ - $\mathrm{P}, 17$-hydroxyprogesterone; $\Delta^{4}$, androstenedione; $T$, testosterone; $17 O H-\Delta^{s} P, 17$-hydroxypregnenolone; $5 \alpha D H T$, dihydrotestosterone (androstanolone); $P$, progesterone; $D H E A$, dehydroepiandrosterone; $\Delta^{5} P$, pregnenolone.

was significantly reduced when the pulse-chase experiments were conducted in the presence of trilostane, a specific inhibitor of $3 \beta$-HSD (Komanicky et al., 1978); and (3) the newly synthesized steroids comigrating with $17 \mathrm{OH}-\mathrm{P}$ were selectively immunodetected using $17 \mathrm{OH}-\mathrm{P}$ antibodies. A good correlation was found between the distribution of $3 \beta$-HSD-immunoreactive neurons and the location of $3 \beta$-HSD bioactivity in the frog brain. In particular, the rhombencephalon that was totally devoid of immunoreactive elements did not exhibit any capability of converting $\Delta^{5} \mathrm{P}$ into $17 \mathrm{OH}-\mathrm{P}, \Delta^{4}$, or $\mathrm{T}$, as shown in Figure $5 B$. This correlation strongly suggests that the $3 \beta$-HSD-immunoreactive material detected in frog hypothalamic neurons corresponds to

Figure 7. Effect of trilostane $\left(10^{-4} \mathrm{M}\right)$ on the conversion of ${ }^{3} \mathrm{H}$-pregnenolone into peak 3 during a $2 \mathrm{hr}$ incubation experiment. The values were obtained from experiments similar to that in Figure 5. Each value

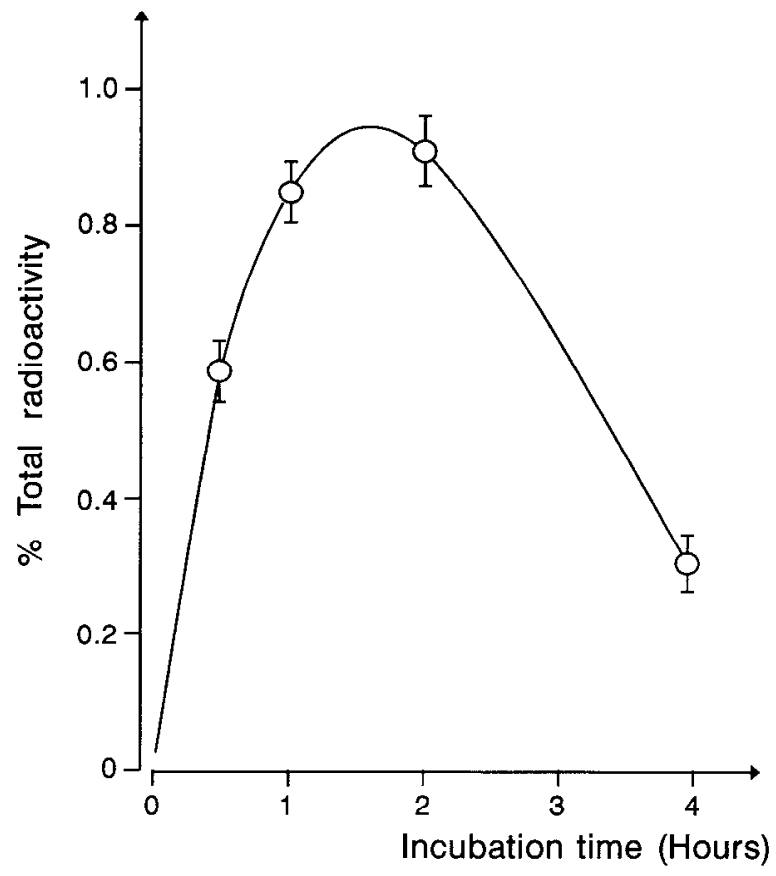

Figure 6. Kinetics of the conversion of ${ }^{3} \mathrm{H}$-pregnenolone into radioactive peak 3 by hypothalamic slices. The values were obtained from experiments similar to that presented in Figure 5. The ordinate represents the relative amount of peak 3 compared to the total amount of radiolabeled compounds resolved by HPLC analysis $(100 \times)$.

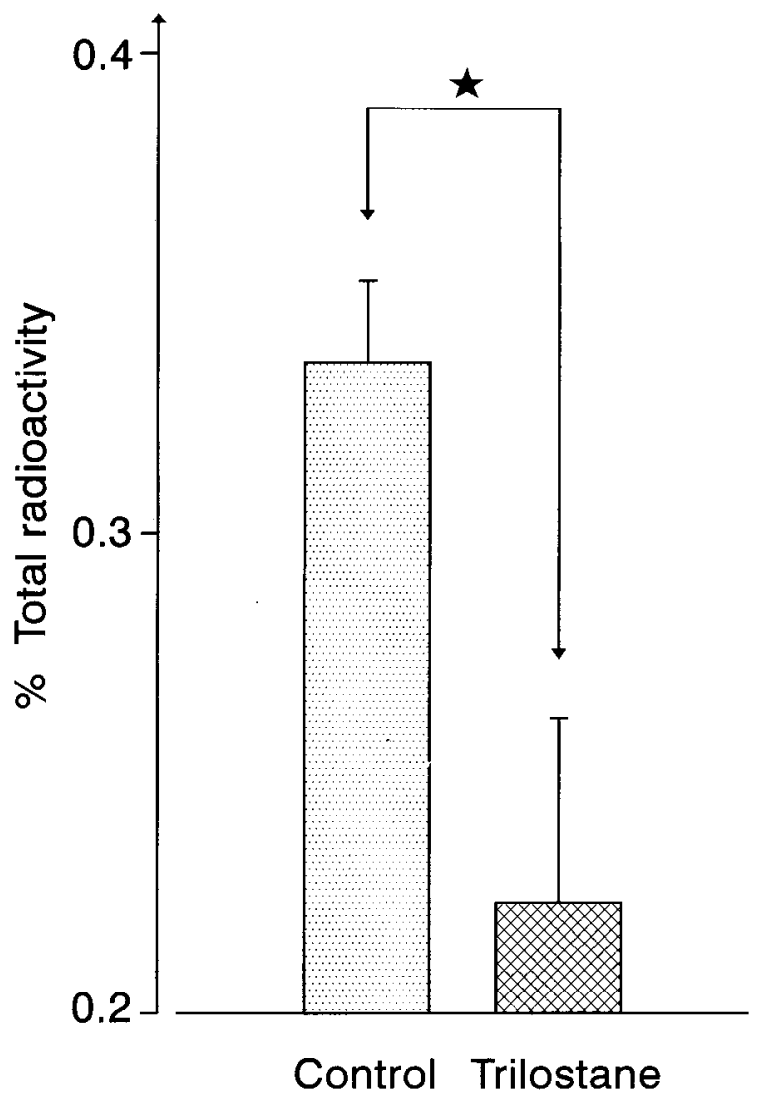

was calculated as the relative amount of peak 3 compared to the total amount of radiolabeled compounds resolved by HPLC analysis $(100 x)$. Each value is the mean ( \pm SEM) of three independent experiments. $\star$, $P<0.05$. 


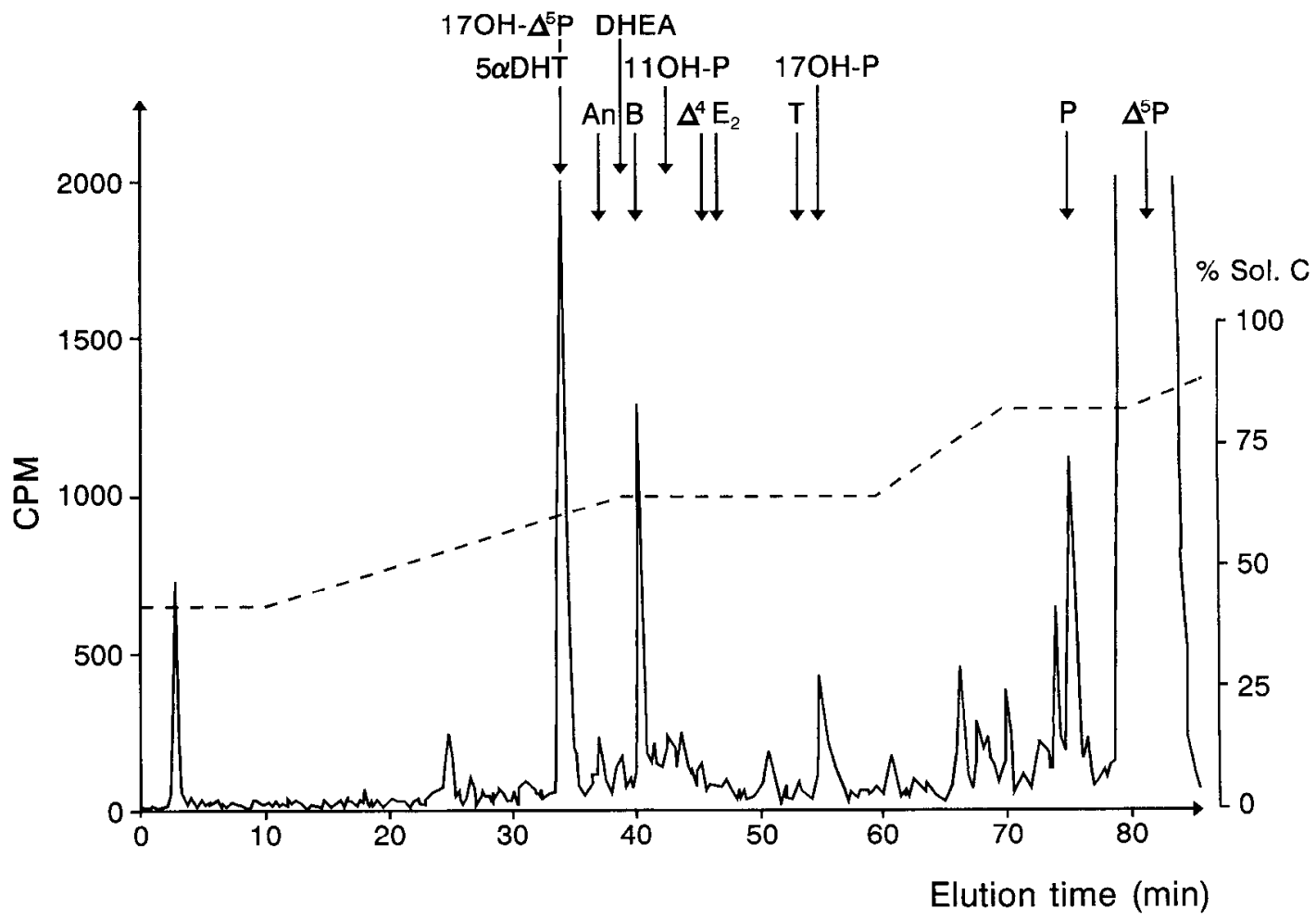

Figure 8. Analysis of steroids extracted from hypothalamic slices after a $2 \mathrm{hr}$ incubation with ${ }^{3} \mathrm{H}$-pregnenolone using a water-TFA/methanol gradient and an HPLC system equipped with a flow scintillation analyzer. The ordinate indicates the radioactivity measured in the HPLC eluent. The dashed line represents the gradient of secondary solvent (\% Sol C). The arrows indicate the elution position of standard steroids: $17 O H-\Delta^{5} P$, 17-hydroxypregnenolone; $5 \alpha D H T$, dihydrotestosterone (androstanolone); $A$, androsterone; $D H E A$, dehydroepiandrosterone; $B$, corticosterone; $11 O H-P, 1$-hydroxyprogesterone; $\Delta^{4}$, androstenedione; $E_{2}$, estradiol; $T$, testosterone; $17 O H-P$, 17 -hydroxyprogesterone; $P$, progesterone; $\Delta^{5} P$, pregnenolone.

an active form of the enzyme. Since conversion of ${ }^{3} \mathrm{H}-\Delta^{5} \mathrm{P}$ into ${ }^{3} \mathrm{H}-17 \mathrm{OH}-\Delta^{5} \mathrm{P}$ may occur (as shown in Fig. 7), it appears that $17 \mathrm{OH}-\mathrm{P}$ may be synthesized through two alternative biosynthetic pathways: $\Delta^{5} \mathrm{P} \rightarrow \mathrm{P} \rightarrow 17 \mathrm{OH}-\mathrm{P}$ and $\Delta^{5} \mathrm{P} \rightarrow 17 \mathrm{OH}-\Delta^{5} \mathrm{P}$ $\rightarrow 17 \mathrm{OH}-\mathrm{P}$.

Interestingly, kinetics experiments showed that the absolute amount of ${ }^{3} \mathrm{H}-17 \mathrm{OH}-\mathrm{P}$ synthesized from ${ }^{3} \mathrm{H}-\Delta^{5} \mathrm{P}$ reached a maximum within $2 \mathrm{hr}$ and rapidly decreased during the next $2 \mathrm{hr}$. This observation indicates that $17 \mathrm{OH}-\mathrm{P}$ is not only an endproduct steroid in the brain, but likely serves as a precursor for other neurosteroids. Biosynthesis of $\Delta^{4}$, a metabolite of $17 \mathrm{OH}$ $P$, has been demonstrated in rat hypothalamic explants incubated with ${ }^{3} \mathrm{H}$-DHEA (Robel et al., 1986). However, the data shown in Figure 7 do not provide evidence for the formation of $\Delta^{4}$ in the frog brain. Concurrently, 17OH-P has never been identified in the CNS of mammals and all attempts to demonstrate $\mathrm{P} 450_{17 \alpha}$-like immunoreactivity have been unsuccessful (for review, see Akwa et a., 1991). It appears, therefore, that substantial differences in the biosynthetic pathways of steroids occur in the brain of various classes of vertebrates. Further experiments are in progress to characterize the different steroids synthesized in the CNS of the frog.

\section{Physiological implications}

Neurosteroids have been shown to have a number of biochemical and behavioral effects (Beaulieu and Robel, 1990). In particular, various neuroactive steroids modulate GABAergic neurotransmission (Akwa et al., 1991). The presence of 3 $\beta$-HSD- immunoreactive neurons in the preoptic and infundibular nuclei of the frog brain, which contain a dense network of GABAergic fibers and nerve terminals (Franzoni and Morino, 1989), suggests that neurosteroids may act presynaptically on GABAergic neurons by controlling the activity of glutamate decarboxylase, as previously shown in the rat brain (Wallis and Luttge, 1980). Alternatively, recent studies revealed that the preoptic nucleus and the dorsal and ventral infundibular nuclei of the frog brain

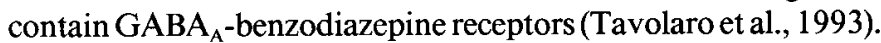
Since several neuroactive steroids act as allosteric modulators of the $\mathrm{GABA}_{\mathrm{A}}$ receptor complex (Majewska, 1992), the present data suggest that steroids synthesized within the frog hypothalamus may regulate GABAergic ncurotransmission postsynaptically by interacting with the $\mathrm{GABA}_{\mathrm{A}}$-benzodiazepine receptor.

In the amphibian brain, the neuronal systems involved in the control of the activity of pituitary cells are generally located in the preoptic nucleus and/or in the dorsal and ventral infundibular nuclei (Andersen et al., 1992). Specifically, neurons producing thyrotropin-releasing hormone (Lamacz et al., 1989), somatostatin (Laquerrière et al., 1989), corticolropin-releasing hormone (Tonon et al., 1985), growth hormone-releasing hormone (Marivoët et al., 1988), neuropeptide Y (Danger et al., 1985), gonadotropin-releasing hormone (Conlon et al., 1993), and pituitary adenylate cyclase-activating polypeptide (Yon et al., 1992) are located in one or several of these hypothalamic nuclei. The occurrence of $3 \beta$-HSD-immunoreactive neurons in these hypothalamic hypophysiotropic centers suggests that neurosteroids may exert neuroendocrine functions by modulating 

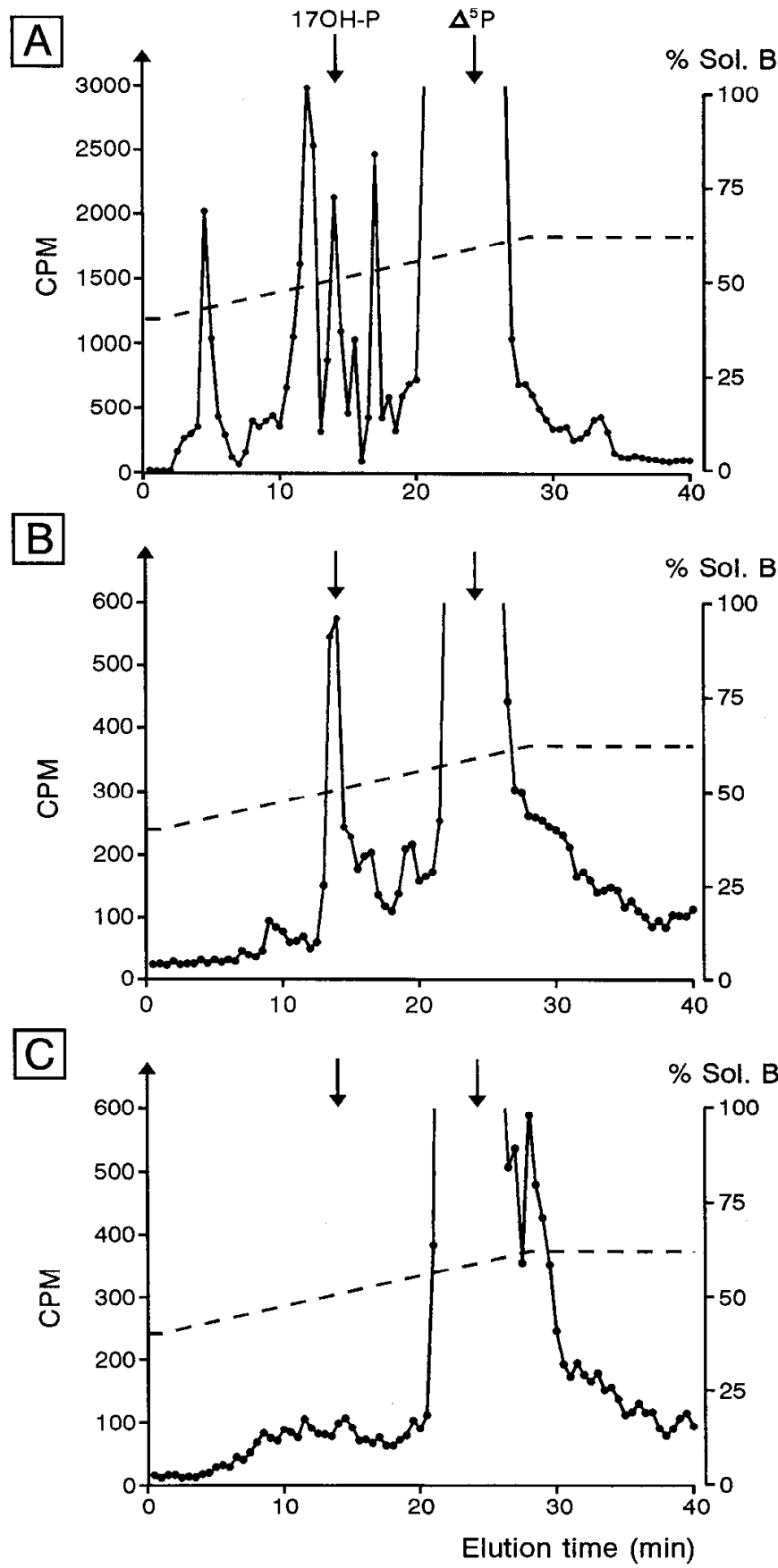

Figure 9. Immunodetection of radiolabeled steroids in the HPLC fractions from frog hypothalamic extracts. The hypothalamic slices were incubated for $2 \mathrm{hr}$ with ${ }^{3} \mathrm{H}$-pregnenolone and the radioactive metabolites were resolved by HPLC analysis. $A$, The content of each HPLC fraction was mixed with liquid scintillator and counted for determination of total radioactivity. $B$ and $C$, The HPLC fractions were evaporated and incubated with $17 \mathrm{OH}-\mathrm{P}$ antiserum diluted $1: 5000(B)$ or nonimmune rabbit serum diluted 1:5000 $(C)$. The radioactivity bound to the antiserum $(B)$ or normal rabbit serum $(C)$ was counted. The dashed line represents the gradient of secondary solvent (\% Sol B). The arrows indicate the elution position of 17-hydroxyprogesterone (17OH-P) and pregnenolone $\left(\Delta^{5} P\right)$.

the biosynthesis and/or release of hypophysiotropic neurohormones. In this respect, possible colocalization of $3 \beta$-HSD with regulatory neuropeptides deserves further investigation.

The presence of $3 \beta$-HSD-like immunoreactivity in long bead- ed nerve fibers indicates that neurosteroids can be synthesized not only in cell bodies but also in axons and thus released at a distance of $3 \beta$-HSD-immunoreactive pcrikarya. In particular, the dense network of $3 \beta$-HSD-immunoreactive fibers visualized in the lateral neuropil of the thalamus appeared to connect the rostral part of the hypothalamus to the tectum. Inasmuch as these tectotegmental connections play a major role in visually elicited orienting movements (Masino and Grobstein, 1990), $3 \beta$-HSD-containing neurons may be involved in the processing of visual information leading to orienting behavior.

In summary, the present study provides the first description of the distribution of $3 \beta$-HSD-like immunoreactivity in the brain. The results demonstrate the existence of three discrete populations of $3 \beta$-HSD-immunoreactive neurons in hypothalamic hypophysiotropic centers. Our study also shows that hypothalamic explants are capable of converting $\Delta^{5} \mathrm{P}$ into $\mathrm{P}$ and $17 \mathrm{OH}$ $P$. Taken together, these data indicate that, in the frog brain, steroids produced in neurons (and not in glial cells) may be involved in the regulation of neuroendocrine functions.

\section{References}

Akwa Y, Young J, Kabbadj K, Sancho MJ, Zucman D, Vourc'h C, Jung-Testas I, Hu ZY, Le Goascogne C, Jo DH, Corpéchot C, Simon P, Baulieu EE, Robel P (1991) Neurosteroids: biosynthesis, metabolism and function of pregnenolone and dehydroepiandro-sterone in the brain. J Steroid Biochem Mol Biol 40:71-81.

Andersen AC, Tonon MC, Pelletier G, Conlon JM, Fasolo A, Vaudry H (1992) Neuropeptides in the amphibian brain. Int Rev Cytol 138: 89-210.

Bain PA, Yoo M, Clarke T, Hammond SH, Payne H (1991) Multiple forms of mouse $3 \beta$-hydroxysteroid dehydrogenase $/ \Delta^{5}-\Delta^{4}$-isomerase and differential expression in gonads, adrenal glands, liver and kidneys of both sexes. Proc Natl Acad Sci USA 88:8870-8874.

Bauer HC, Bauer H (1989) Micromethod for the determination of $3 \beta$ HSD activity in cultured cells. I Steroid Biochem 33:643-646.

Baulieu EE, Robel P (1990) Neurosteroids: a new brain function? J Steroid Mol Biol 37:395-403.

Conlon JM, Collin F, Chiang YC, Sower SA, Vaudry H (1993) Two molecular forms of gonadotropin-releasing hormone from the brain of the frog, Rana ridibunda. Purification, characterization and distribution. Endocrinology 132:2117-2123.

Corpéchot C, Young J, Calvel M, Wehrey C, Veltz JN, Touyer G, Mouren M, Prasad VVK, Banner C, Sjövall J, Baulieu EE, Robel P (1993) Neurosteroids: $3 \alpha$-hydroxy-5 $\alpha$-pregnan-20-one and its precursors in the brain, plasma, and steroidogenic glands of male and female rats. Endocrinology 133:1003-1009.

Danger JM, Guy J, Benyamina M, Jégou S, Leboulenger F, Côté J, Tonon MC, Pelletier G, Vaudry H (1985) Localization and identification of neuropeptide Y (NPY)-like immunoreactivity in the frog brain. Peptides 6:1225-1236.

Dupont E, Luu-The V, Labrie F, Pelletier G (1990a) Ontogeny of $3 \beta$ hydroxysteroid dehydrogenase $/ \Delta^{5}-\Delta^{4}$-isomerase ( $3 \beta$-HSD) in human adrenal gland performed by immunocytochemistry. Mol Cell Endocrinol 74:R7-R 10 .

Dupont E, Luu-The V, Labrie F, Pelletier G (1990b) Light microscopic immunocytochemical localization of $3 \beta$-hydroxy-5- ene-steroid dehydrogenase $/ \Delta^{5}-\Delta^{4}$-isomerase in the gonads and adrenal glands of the guinea pig. Endocrinology 126:2906-2909.

Dupont E, Zhao H, Rhéaume E, Simard J, Luu-The V, Labrie F, Pelletier G (1990c) Localization of $3 \beta$-hydroxysteroid dehydrogenase $/ \Delta^{5}-\Delta^{4}-$ isomerase in rat gonads and adrenal glands by immunocytochemistry and in situ hybridization. Endocrinology 127:1394-1403.

Dupont E, Simard J, Luu-The V, Labric F, Pelletier G (1994) Localization of $3 \beta$-hydroxysteroid dehydrogenase in rat brain as studied by in situ hybridization. Mol Cell Neurosci 5:119-123.

Franzoni MF, Morino P (1989) The distribution of GABA-like- immunoreactive neurons in the brain of the newt, Triturus cristatus carnifex, and in the green frog, Rana esculenta. Cell Tissue Res 255: $155-166$.

Jacobowitz DM (1988) Multifactorial control of pituitary hormone secretion: the "wheels" of the brain. Synapse 2:186-192. 
Jung-Testas I, Hu ZY, Baulieu EE, Robel P (1989) Neurosteroids: biosynthesis of pregnenolone and progesterone in primary cultures of rat glial cells. Endocrinology 125:2083-2091.

Kabbadj K, El-Etr M, Baulieu EE, Robel P (1993) Pregnenolone metabolism in rodent embryonic neurons and astrocytes. Glia 7:170175.

Komanicky P, Spark RF, Melby JC (1978) Treatment of Cushing's syndrome with trilostane (WIN 24,540), an inhibitor of adrenal steroid biosynthesis. J Clin Endocrinol Metab 47:1042-1051.

Labrie F, Simard J, Luu-The V, Pelletier G, Bélanger A, Lachance Y, Zhao HF, Labrie C, Breton N, De Launoit Y, Dumont M, Dupont E, Rhćaumc E, Martcl C, Couct J, Trudel C (1992) Structure and tissue-specific expression of $3 \beta$-hydroxysteroid dehydrogenase/ 5 -ene4-ene isomerase genes in human and rat classical and peripheral steroidogenic tissues. J Steroid Biochem Mol Biol 41:421-435.

Lachance Y, Luu-The V, Labrie C, Simard J, Dumont M, De Launoit Y, Guérin S, Leblanc G, Labrie F (1990) Characterization of human $3 \beta$-hydroxysteroid dehydrogenase $/ \Delta^{5}-\Delta^{4}$-isomerase gene and its expression in mammalian cells. J Biol Chem 265:20469-20475.

Lachance Y, Luu-The V, Verreault H, Dumont M, Rhéaume E, Leblanc G, Labrie F (1991) Structure of the human type Il 3 $\beta$-hydroxysteroid dehydrogenase $/ \Delta^{5}-\Delta^{4}$-isomerase ( $3 \beta$-HSD) gene: adrenal and gonadal specificity. DNA Cell Biol 10:701-711.

Lamacz M, Hindelang C, Tonon MC, Vaudry H, Stoekel ME (1989) Three distinct thyrotropin-releasing hormone immunoreactive axonal systems project in the median eminence-pituitary complex of the frog Rana ridibunda. Immunocytochemical evidence for co-localization of thyrotropin-releasing hormone and mesotocin in fibers innervating pars intermedia cells. Neuroscience 32:452-462.

Laquierrière A, Leroux P, Gonsalez B, Bodenant C, Benoit R, Vaudry H (1989) Distribution of somatostatin receptors in the brain of the frog Rana ridibunda: correlation with the localization of somatostatin-containing neurons. J Comp Neurol 280:451-467.

Leboulenger F, Bélanger A, Delarue C, Leroux P, Netchitailo P, Perroteau I, Roullet M, Jegou S, Tonon MC, Vaudry H (1981) In vitro study of frog (Rana ridibunda Pallas) interrenal function by use of a simplified perfusion system. V. Influence of adrenocorticotropin upon progesterone production. Gen Comp Endocrinol 45:465-472.

Le Goascogne C, Robel P, Gouézou M, Sananès N, Baulieu EE, Waterman M (1987) Neurosteroids: cytochrome P-450 scc $_{\text {in }}$ in brain. Science 237:1212-1215.

Luu-The V, Lachance Y, Labrie C, Leblanc G, Thomas JL, Strickler RC, Labrie F (1989) Full length cDNA structure and deduced amino acid sequence of human $3 \beta$-hydroxy-5-ene steroid dehydrogenase. Mol Endocrinol 3:1310-1319.

Majewska MD (1992) Neurosteroids: endogenous bimodal modulators of the $\mathrm{GABA}_{\mathrm{A}}$ receptor. Mechanism of action and physiological significance. Prog Neurobiol 38:379-395.

Malagon M, Vaudry $\mathrm{H}$, Vallarino M, Gracia-Navarro F, Tonon MC (1992) Distribution and characterization of endozepine-like immunoreactivity in the central nervous system of the frog Rana ridibunda. Peptides 13:99-107.
Marivoët S, Moons L, Vandesande F (1988) Localization of growth hormone-releasing factor-like immunoreactivity in the hypothalamo-hypophyseal system of the frog (Rana temporaria) and the sea bass (Dicentrarchus labrax). Gen Comp Endocrinol 72:72-79.

Masino T, Grobstein P (1990) Tectal connectivity in the frog Rana pipiens: tectotegmental projections and a general analysis of topographic organization. J Comp Neurol 291:103-127.

Nagle RB (1988) Intermediate filaments: a review of the basic biology. Am J Surg Pathol 12:4-16.

Northcutt RG, Kicliter E (1980) Organization of the amphibian telencephalon. In: Comparative neurology of the telencephalon (Ebbeson SOE, ed), pp 203-255. New York: Plenum.

Oksche A, Ueck M (1976) The nervous system. In: Physiology of the amphibia, Vol III (Lofts B, ed), pp 329-333. New York: Academic.

Raff MC, Mirsky R, Fields KL, Lisak RP, Dorfamn SH, Silberbery DH, Gregson NA, Leibowitz S, Kennedy MC (1978) Galactocerebroside is a specific cell-surface antigenic marker for oligodendrocytes in culture. Nature 274:813-816.

Robel P, Corpéchot C, Clarke C, Groyer A, Synguelakis M, Vourc'h C, Baulieu EE (1986) Neuro-steroids: $3 \beta$-hydroxy- $\Delta 5$-derivates in the rat brain. In: Neuroendocrine molecular biology (Fink AJ, Harmar AJ, McKerns KW, eds), pp 367-377. New York: Plenum.

Tavolaro R, Canonaco M, Franzoni MF (1993) A quantitative autoradiographic study of $\mathrm{GABA}_{\mathrm{A}}$ and benzodiazepine receptors in the brain of the frog Rana esculenta. Brain Behav Evol 42:171-177.

Tonon MC, Burlet A, Lauber M, Cuet P, Jégou S, Gouteux L, Vaudry $H$ (1985) Immunohistochemical localization and radioimmunoassay of corticotropin-releasing factor in the forebrain and hypophysis of the frog Rana ridibunda. Neuroendocrinology 40:109-119.

Wada M, Urano A, Gorbman A (1980) A stereotaxic atlas for diencephalic nuclei of the frog Rana pipiens. Arch Histol Jpn 43:157173.

Wallis C, Luttge W (1980) Influence of estrogens and progesterone on glutamic acid decarboxylase activity in discrete regions of rat brain. J Neurochem 34:609-613.

Weidenfield J, Sziegel RA, Chowers I (1980) In vitro conversion of pregnenolone to progesterone by discrete brain areas of the male rat. J Steroid Biochem 13:961-963.

Yon L, Feuilloley M, Chartrel N, Arimura A, Conlon JM, Fournier A, Vaudry H (1992) Immunocytochemical distribution and biological activity of pituitary adenylate cyclase-activating polypeptide (PACAP) in the central nervous system of the frog Rana ridibunda. $\mathrm{J}$ Comp Neurol 324:485-499.

Zhao HF, Labrie C, Simard J, De Launoit Y, Trudel C, Martel C, Rhéaume E, Dupont E, Luu-The V, Pelletier G, Labrie F (1991) Characterization of rat $3 \beta$-hydroxy-5-ene-steroid dehydrogenase $/ \Delta^{5}$ $\Delta^{4}$-isomerase cDNAs and differential tissue-specific expression of corresponding mRNAs in steroidogenic and peripheral tissues. J Biol Chem 266:583-593. 